\title{
The Impact of Civil Conflict on Child Malnutrition and Mortality, Nigeria, 2002-2013
}

\section{Embry Howell, Timothy Waidmann, Nikhil Holla, Nancy Birdsall, and Kevin Jiang}

\begin{abstract}
The new millennium brought renewed attention to improving the health of women and children. In this same period, direct deaths from conflicts have declined worldwide, but civilian deaths associated with conflicts have increased. Nigeria is among the most conflict-prone countries in sub-Saharan Africa, especially recently with the Boko Haram insurgency in the north. This paper uses two data sources, the 2013 Demographic and Health Survey for Nigeria and the Social Conflict Analysis Database, linked by geocode, to study the effect of these conflicts on child health. We show a strong association between living close to a conflict zone and acute malnutrition in Nigerian children in 2013. This is related to the severity of the conflict, measured both in terms of the number of conflict deaths and the length of time the child was exposed to conflict. The association with mortality is much less clear, with essentially no significant relationship to conflict detected using these data for the period studied. Undoubtedly civil conflict is limiting the future prospects of Nigerian children and the country's economic growth. In Nigeria conflicts in the north are expected to continue with sporadic attacks and continued damaged infrastructure. Thus, the children in Nigeria will continue to suffer the consequences documented in this study.
\end{abstract}




\title{
The Impact of Civil Conflict on Child Malnutrition and Mortality, Nigeria, 2002-2013
}

\author{
Embry Howell \\ Urban Institute Health Policy Center \\ Timothy Waidmann, \\ Urban Institute Health Policy Center \\ Nikhil Holla \\ Urban Institute Health Policy Center \\ Nancy Birdsall \\ Center for Global Development \\ Kevin Jiang \\ Baylor University Medical School* \\ *Rice University Baker Institute at the time of research
}

Center for Global Development 2055 L Street NW Washington, DC 20036

202.416.4000

(f) 202.416 .4050

www.cgdev.org
We acknowledge the excellent comments of two reviewers-Seb Bauhoff and Alex Ezeh of the Center for Global Development-and of participants at a seminar at CGD on January 25, 2018. We greatly appreciate the availability of public-use data from the Demographic and Health Surveys and the Social Conflict in Africa Database.

Embry Howell, Timothy Waidmann, Nikhil Holla, Nancy Birdsall, and Kevin Jiang, 2018. "The Impact of Civil Conflict on Child Malnutrition and Mortality, Nigeria, 2002-2013." CGD Working Paper 494. Washington, DC: Center for Global Development. https:// www.cgdev.org/publication/impact-civil-conflict-child-malnutrition-and-mortality-nigeria

The Center for Global Development works to reduce global poverty and improve lives through innovative economic research that drives better policy and practice by the world's top decision makers. Use and dissemination of this Working Paper is encouraged; however, reproduced copies may not be used for commercial purposes. Further usage is permitted under the terms of the Creative Commons License.

The views expressed in CGD Working Papers are those of the authors and should not be attributed to the board of directors, funders of the Center for Global Development, or the authors' respective organizations. 


\section{Contents}

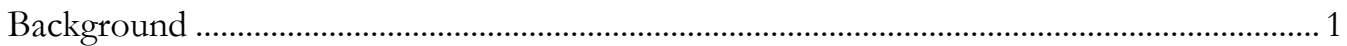

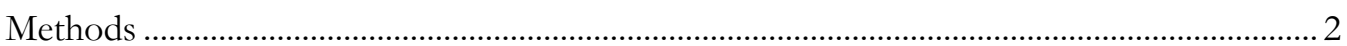

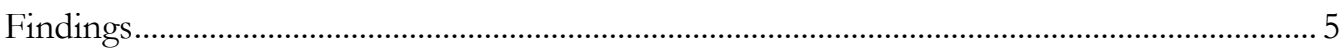

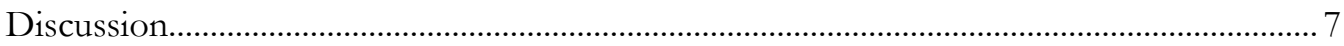

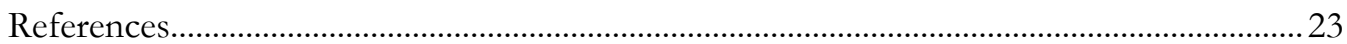




\section{Background}

The new millennium brought renewed attention to improving the health of women and children, resulting in the adoption of the Millennium Development Goals for 2015 and, more recently, the Sustainable Development Goals for 2030 (World Health Organization, 2015). In establishing these goals, the nations of the world came together to attempt to reduce hunger, infant mortality, and child mortality, with specific targets worldwide. Developing countries, especially sub-Saharan African countries, face particular challenges meeting these ambitious goals.

In this same period, direct deaths from conflicts have declined worldwide, but civilian deaths associated with conflicts have increased (World Health Organization, 2015) (Kruk, Freedman, Anglin, \& Waldman, 2010). Armed conflicts are more likely to occur in poor countries with weak states, particularly in sparsely populated rural areas and in places where there is competition for land and water (Blattman \& Miguel, 2010). The civilian deaths can result from malnutrition due to loss of farms or herds and disruption of the food supply chain. In addition, the supply of health services may decline just where it is most needed (Pike, Straight, Oesterle, Hilton, \& Lanyasunya, 2010) (Safeguarding Health in Conflict Coalition, 2017).

Numerous studies have shown the negative health impact of such conflicts on civilians, particularly children. Table 1 summarizes findings from 14 empirical studies from 11 countries (six in Africa) concerning the impact of armed conflict on child health. While no study is completely free from methodological limitations, the combined results suggest what is intuitively obvious: that — across many countries — there is a substantial negative effect on child health from war and conflict. However, caution is needed, because design flaws can lead to inaccurate conclusions. One study in Ethiopia concluded that, while there was a correlation between conflict and child health, after controlling for drought, conflict events did not have a significant effect on child health (Delbiso, Rodriguez-Llanes, Donneau, Speybroeck, \& Guha-Sapir, 2017). But, in addition, the size of effects cannot be generalized from the studies because of substantial methodological differences. For example, the child health outcomes in these studies are quite varied, including infant and child mortality as well as various measures of poor nutritional status, such as small weight-for-age, height-for-age, or weight-for-height (generally called "wasting" or "acute malnutrition"). Counting the number of conflicts, and the characteristics of those conflicts, is challenging and different data sources tally such events in different ways, each with potential biases (Johnson, Spagat, \& Gourley, 2008). The most common limitation among the studies cited in table 1 is that conflict exposure was generally measured by residence in a country, region, province, or district where conflict was underway for a period of time. A particular mother's or child's exposure to conflict and the intensity of that person's exposure, as distinct from any other resident of the same geographic area, generally was not measured. Other limitations of one or more studies include use of aggregate data from a variety of surveys; small sample sizes; and a lack of adjustment for maternal, child, or household characteristics.

Armed conflict is prevalent in sub-Saharan Africa. Nigeria is among the most conflict-prone countries in the region, experiencing the highest number of conflict-related deaths of all sub- 
Saharan African countries in many of the years since 2000 (ACLED, n.d.). Since 2000 when civilian government took hold, Nigeria has experienced conflict in the Niger Delta around control of oil fields and oil wealth; conflicts in many parts of the country, particularly in the "middle belt," concerning competition for land, often with ethnic and religious affiliation underpinnings; and more recently (since 2011) the Boko Haram insurgency in the north (Project Ploughshares, n.d.). One data source documents 32,942 deaths from social violence in Nigeria during the period 1998 to 2014. Of these, 42 percent were due to the Boko Haram insurgency (all since 2009). Another 45 percent were communal/ethnic/religious or herder/farmer conflicts. The remainder were due to state or political violence (Nigeria Social Violence Project, n.d.).

Figure 1 shows trends from 2003 to 2013 in the number of Nigerian civil conflicts as documented in the Social Conflicts Analysis Database (SCAD, n.d.). The number of conflicts varied from 30 in 2008 to 114 in 2013. Most (77.7 percent) conflicts were armed conflicts. Conflict in the period peaked in 2013 due to the Boko Haram insurgency. There are variations in the number of deaths per year, from 844 in 2008 to 2350 in 2013. Figure 2 shows the location of the conflicts in 2012 and the size of conflicts in terms of number of deaths.

The effect of conflict on Nigerian children's health has not been studied, even though the country is one of the most conflict-prone in the world. The purpose of this study is to add to existing literature by documenting the effect of conflict on child health in Nigeria by improved empirical methods.

\section{Methods}

Conceptual framework. Figure 3 provides a conceptual framework for how civil conflict may affect child nutrition and health. Civil conflict can lead to (among many factors): maternal stress during pregnancy (which affects health in utero and early life); displacement from food, shelter, and safe water (leading to malnutrition, diarrheal disease, and reduced resistance to other diseases); disruption in food supply (leading to acute malnutrition); potentially fatal injuries from direct exposure to violence; and a destruction or disruption of health services that may prevent access to life-saving treatments. All of these may ultimately lead to infant and child mortality.

Data sources. We use two data sources, linked together by geocode. The first is the 2013 Demographic and Health Survey (DHS) for Nigeria, one of hundreds of DHS surveys that have been conducted in 90 developing countries since 1985. The DHS assesses the health, nutrition, and socioeconomic characteristics of a nationally representative sample of women and their children (Demographic and Health Surveys, n.d.). The second is the Social Conflict Analysis Database (SCAD, n.d.), a database compiled from reports of conflicts reported by two wire services, the Associated Press and Agence France Presse. Both the DHS and the SCAD include geocode data in the form of longitude and latitude coordinates; in the case of DHS these codes identify the location of the interview (the centroid of cluster for the household), and in the case of SCAD they identify the location of the conflict. The two data sources (SCAD and DHS) were linked using this geocode. Our dataset consists of a record 
for each Nigerian child in the survey and all conflicts that were within a predefined radius around the child's household at the time of the survey.

Outcome and control measures. The DHS is an in-person interview with mothers. It asks her questions about her health and fertility and that of members of her household. In particular, for this study, she reports the birth dates for each of her children and death dates for those who died. In addition, children under 5 are measured by the interviewer for height and weight. The survey responses are used to construct four outcome measures for this study:

- The $z$ score for weight for height: the number of standard deviations above or below the norm weight for height for children as defined by the World Health Organization (World Health Organization, n.d.), multiplied by 100.

- Acute malnutrition, hereafter called "wasting" and defined as weight for height more than 2 standard deviations below the norm as defined by the World Health Organization;

- Infant death, and

- Child death at ages 1-4.

Demographic variables, used as control in the regression models, are as follows:

- Child characteristics: birth order, year of birth, gender, number of months since birth of previous sibling (with the overall average used for first order births).

- Maternal characteristics: age at each child's birth, marital status at time of interview, length of education, ethnicity (tribe).

- Household characteristics: region, wealth index quintile (constructed from numerous DHS indicators such as housing quality), household size.

Conflict exposure. From the SCAD we developed two indices of child exposure to conflict, with the assumption that a conflict with a higher number of deaths or that lasted longer would have more serious consequences for the child's health. Thus, conflict exposure is measured by exposure to conflict deaths and by length of exposure. In addition, we assumed that a conflict that was further away would have less consequence for a child's health. The number of conflict deaths is weighted inversely by distance to the mother's home at the time of the interview. ${ }^{1}$ For example, a death within one $\mathrm{km}$ of the home has a weight of 1, a death within $2 \mathrm{~km}$ has a weight of .5, etc. Deaths to conflicts outside a $10 \mathrm{~km}$ radius for urban children and a $25 \mathrm{~km}$ radius for rural children are given a weight of zero. A child can be exposed to more than one conflict in a given period, and if so, all deaths are included in the exposure measure. Similarly, a measure of length of exposure in days, also weighted by distance in a similar manner to deaths, is used. In this measure, a child does not necessarily experience the entire duration of the conflict; only those days with one or more conflicts within the child's exposure period are counted.

${ }^{1}$ We considered interacting the number of conflict deaths and length of exposure with distance, but this would require reconfiguring the data files by event rather than by child. 
Time frame. All data on outcomes derive from the DHS survey conducted in 2013. We assume a lag in the effect of exposure to conflict on child health. For the wasting analysis, the exposure to conflict period is the year before the survey date. The child's height and weight are measured at the time of the survey for infants and 1-4-year-olds. For the mortality measures it is possible to go back in time to measure outcomes for each of a mother's children. We linked data from the SCAD to the DHS for all children born during and after 2003. Infant mortality is measured for all children born up to 2012 (a 10-year time period). For measuring child mortality, the sample was restricted to children born in the first half of that period (2003 to 2007) to allow for a five-year survival period. For infant mortality, exposure is during the one year prior to the child's birth, since much of infant mortality occurs in the first days and weeks after birth (UNICEF, n.d.) and the harm is primarily due to maternal exposure during pregnancy. Exposure for child mortality (ages 14) is measured during the child's first year of life. ${ }^{2}$

Data limitations. The DHS has a major limitation for the purposes of this study, in that location data (which are merged with the SCAD) are collected at the time of the survey. However, thousands of people have been displaced from their homes during the Nigerian civil conflicts of the study period (Project Ploughshares, n.d.). Consequently, when a mother is interviewed she may not reside at or near the place where she gave birth or where a particular child lived during the exposure period. Even for the wasting analysis, where exposure is measured in the year before the survey, thus reducing the likelihood of displacement, a mother may be interviewed at a different location from the place of the conflict. This inserts a substantial measurement bias in the conflict exposure data. It is not clear whether the bias is in a favorable or unfavorable direction. For example, people who are better off (and with better outcomes) may have a better ability to move, but those who are worse off (and with poorer outcomes) may be more motivated to move, especially persecuted ethnic groups. In the first circumstance, the bias would be in the direction of finding an effect of the impact of conflict and vice versa for the second circumstance. This problem with using DHS data for the analysis of conflict effects was noted in the first DHS study of this topic (Savitz, Thang, Swenson, \& Stone, 1993) and continues today. The bias is likely larger for our analysis of infant and child mortality, which rely on reports of children's deaths up to 10 years before the survey. However, it is necessary to use that many years of data to obtain stable rates for these relatively rare events. Wasting, which is more common, can be measured for a single year. A second limitation of these data is that even if no migration occurred, distance to a conflict is measured relative to the geographic centroid of a survey cluster rather than to the precise location of the mother's home. (Cluster are generally small geographic areas.) This introduces random measurement error in the key independent variable, which tends to bias coefficient estimates toward zero, reducing the likelihood of finding a significant effect.

There are several large databases that tabulate the number and location of conflicts in Africa and other countries, as well as the type and length of the conflict and the number of deaths

${ }^{2}$ A sensitivity analysis examining mortality only between ages 1 and 2 gave similar results to the findings we present for mortality for all 1-4-year-olds. 
associated with it. One of the most often used is the previously mentioned ACLED. Both the SCAD and the ACLED document conflicts in Nigeria over the study period. However, one major difference between the data sets is the sources for reports of conflicts, locations, and conflict deaths. For the SCAD, these come from only two sources, the Associated Press and Agence France Presse news wires. In contrast, the ACLED uses up to 50 local, regional, national, and continental media sources. Not surprisingly, the ACLED documents about twice as many conflict deaths as the SCAD. We chose the more conservative data source in terms of numbers of conflicts and conflict deaths, which likely underreports small localized conflicts, but is likely more consistent over time.

\section{Findings}

Table 2 shows the characteristics of the study group for the wasting analysis. While the study group populations differ for the infant and child mortality analyses, the characteristics of the samples are very similar and are not shown. The study groups are characterized by children in large families (average family size of 6.6 in urban areas and 7.4 in rural areas). In addition, rural residents are much poorer than urban residents. Only 3.0 percent of urban residents are in the poorest quintile compared to 33.5 percent of rural residents. Rural residents are concentrated in the northern regions.

Unadjusted wasting, infant mortality, and child mortality rates in 2013 for children in the study groups are shown in table 3. Our analysis of the DHS survey shows the Nigerian child wasting rate to be 19.2 percent of children ages $0-4$ in 2013, which is very high. Nigeria also has among the highest infant and child mortality rates in sub-Saharan Africa. Nigeria's 2013 infant mortality rate was 77 per 1000 (60 per 1000 for urban children and 85 per 1000 for rural children). Across sub-Saharan Africa, in 2012 the rate was considerably lower, 63 per 1000 for all children (World Health Organization, 2014). Nigerian child mortality is also relatively high: 39 per 1000 for urban children and 84 per 1000 for rural children.

Table 4 shows the average exposure of children in the sample to conflicts and conflict deaths. The table shows both absolute numbers of conflicts and conflict deaths as well as the number of deaths weighted by distance from conflict. Keeping in mind the potential location bias discussed above, the data suggest that Nigerian children were exposed to many conflicts during the study period, especially for the wasting analysis which took place during the Boko Haram insurgency. For the wasting analysis, an urban child was exposed to an average of 4.32 conflicts in the year prior to the survey, while a rural child was exposed to an average of 1.04 conflicts. In contrast, for the infant mortality analysis exposure was much lower, an average of .79 conflicts (urban) and .20 conflicts (rural) annually in the exposure period (unweighted). The number of conflicts for the child mortality analysis were similarly much lower than for the wasting analysis. The average annual number of conflict deaths for the wasting analysis was 8.94 deaths (urban children) and 2.43 deaths (rural children). After weighting for distance, those numbers become 1.83 deaths for urban children and only 0.14 deaths for rural children. For the wasting analysis, the average length of conflicts was 11.85 days (urban) vs. 3.08 days (rural) during the year before the survey. After weighting for distance, this conflict measure is 2.78 days (urban) and 0.16 days (rural). 
Table 5 presents results from four logistic regression analyses of the impact of exposure to conflict on child wasting. Separate models are presented for urban and rural children, as well as separate models for the two conflict measures, conflict deaths and conflict duration. All four regressions show consistently that conflict is positively and significantly associated with child wasting (acute malnutrition). For example, the odds of experiencing wasting are 5 percent higher for every unit increase in the conflict death index (deaths $/ \mathrm{km}$, e.g., 1 death within $1 \mathrm{~km}, 2$ deaths within $2 \mathrm{~km}$, etc.) in urban areas, and 17 percent higher in rural areas (borderline significance). This is a substantial increase in the odds of wasting for the average child, especially for urban children who are exposed to more conflicts.

It is possible that a lack of access to good nutrition affects all children throughout the weight for height spectrum. For example, children who have an excellent weight for height may lose weight, even though they do not become acutely malnourished (wasted). To examine whether the relationship of conflict to child nutritional status is continuous throughout the weight for height spectrum, we modeled the continuous $Z$ score as shown in table 6. Figure 4 shows four histograms illustrating the distribution of the $Z$ scores for Nigerian children, separately for urban and rural children. They illustrate that, for both urban and rural children, the score is skewed, reflecting more Nigerian children below the norm. This is especially so for children who have experienced conflict. However, there is no clear-cut point, suggesting a gradually declining nutritional status below the norm. Table 6 provides the results of the ordinary least squares regression modeling the relationship between conflict and Z Scores. This regression also shows a strong and significant relationship between both the number of conflict deaths weighted by distance and the duration of the conflict weighted by distance. For example, using the conflict death measure, for urban areas a conflict death within one $\mathrm{km}$ leads to a decrease of .059 standard deviation from the WHO norm of weight for height for the child's age.

We performed several additional regression analyses to augment the basic analysis of the relationship between conflict and wasting, or to test the sensitivity of the results to alternative specifications. The results are summarized in table 7 , with detailed regression results provided in appendix tables $1-4$. First, since the wealth index is potentially correlated with both conflict (due to the impact of conflict on a family's income and assets) and education, wealth is excluded from the basic model presented in table 5. Table 7 and appendix table 1 show that including the wealth index in the regression makes almost no difference in the size of the odds ratios for the conflict measures (and wealth is insignificant in the regressions). Second, given concern about the lack of good information on whether a mother moved from the location of the conflicts to the location of the survey, we performed a sensitivity analysis for the wasting analysis. The conflicts with Boko Haram are concentrated in the north of Nigeria. When surveys from the Northeast region are eliminated, results are very similar to the original analysis shown in table 5 (see appendix table 2). For example, for urban children and for the conflict death measure of conflict intensity, the odds ratio is 1.05 in the main analysis and 1.08 without children in the Northeast region; both ratios are highly significant $(\mathrm{p}<.01)$.

However, when both the Northeast and the Northwest regions are eliminated, results do change and there is no longer a significant effect of conflict on wasting (data not shown). 
This illustrates that the results are sensitive to region, and that the conflicts in the north are driving the results. Thus, the results we present are an average across Nigeria, and do not reflect region-specific findings. Likely, if there was sufficient sample size to analyze data by region, the northern regions would show larger effects and the results in the south would be smaller or non-significant.

The results for four more logistic regression analyses are shown in table 7 (appendix tables 3 and 4). Given the previous literature showing a relationship of conflict to either infant or child mortality, we examined these outcomes using the same regression models as for child wasting. However, as shown, the relationship between conflict and infant or child mortality is much less clear than for child wasting. There is only one significant finding, for infant mortality for urban children (borderline significant, $\mathrm{p}<.10$ ). Two factors could contribute to this lack of clear relationship: (1) the exposure of children to conflict was much greater using the one year exposure period (2012) for the wasting analysis than the 10-year period (20022012) for the mortality analysis, and (2) the possibility of migration out of the north was greater because of the longer analysis period for the infant and child mortality analyses. In addition, the small number of deaths increases variability and reduces power to detect differences.

\section{Discussion}

This paper has shown a strong association between living close to a conflict zone and acute malnutrition (wasting) in Nigerian children in 2013. This is related to the severity of the conflict, as measured both in terms of the number of conflict deaths and the length of time the child was exposed to conflict. For example, urban children have about 5 percent greater odds of being wasted for each conflict day or death they are exposed to. Findings for rural children are even stronger with odds ratios of 1.13 or 1.17 depending on the conflict measure. The analysis of Z-scores shows that not only the most acutely malnourished children are affected by conflict. The average child moves further below the international norm of weight for height with the increase in conflict intensity. The association with mortality much less clear, with essentially no significant relationship to conflict detected using these data for the period studied. As noted, this could be due to data limitations.

The suffering of small children is often an unrecognized outgrowth of civil conflict. However, undoubtedly civil conflict is limiting the future prospects of Nigerian children and the country's economic growth. As pointed out in the recent Global Nutrition Report, malnutrition "is a problem of staggering size-large enough to threaten the world's sustainable development ambitions" (International Food Policy Research Institute, 2015).

Our findings are generally consistent with findings from other countries on the negative impact of conflict on child nutrition and health. However, these results provide an improved methodology for relating the size, duration, and location of a conflict to a child's outcomes. Previous studies, such as those cited above, have examined conflicts in a particular region of a country but have not distinguished between how close the conflict was to the mother and child's residence, and generally have not examined conflict severity. In addition, previous 
studies have not examined Nigeria, where conflict has become endemic in certain parts of the country.

There is a lack of good evidence on what works to minimize the profound negative effects of conflict on children. De Jong suggests that conflict should be treated as a public health problem, with primary, secondary, and tertiary interventions (De Jong J. T., 2010). Primary prevention would consist of addressing the underlying causes of conflict (for example, corrupt governments; lack of education and jobs; the flow of small arms into countries; and increasing drought, among many others). Secondary prevention consists of numerous targeted interventions, such as food assistance and "therapeutic feeding" (for example, using enriched foods) for malnourished children (Young H. , Borrel, Holland, \& Salama, 2004) (Maternal and Child Undernutrition Study Group, 2008). Tertiary prevention includes peacekeeping after the conflict to avoid recurrence as well as rehabilitation of education and health facilities. A recent World Bank report suggests several ways that the bank could improve its assistance to post-conflict countries to address children's health, such as institutional support to ministries of health and to local governments, more flexible financing, and more explicit efforts to address the health needs of children post-conflict (Bustreo, Genovese, Omobono, Axelsson, \& Bannon, 2005).

Conflicts creating humanitarian crises are forecast for 17 countries around the world for 2018. In particular, in Nigeria conflicts in the north are expected to continue with sporadic attacks and continued damaged infrastructure (ACAPS, 2017). Thus, the children in Nigeria will continue to suffer the consequences documented in this study. This makes a response from civil society, donors, and governments all the more timely and urgent. 
Figure 1. Trends in Nigerian Conflict Deaths, 2003-2013

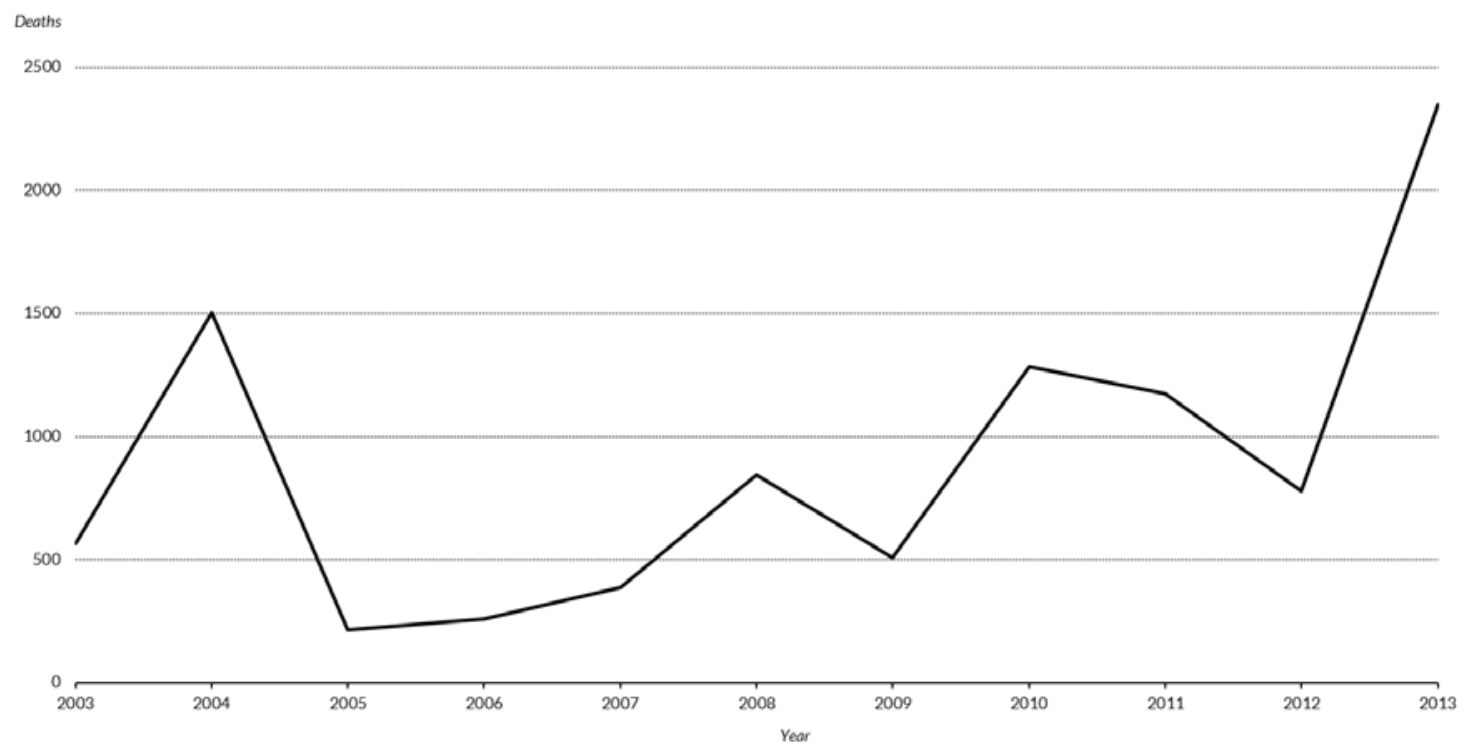

Source: Social Conflict Analysis Database (SCAD)

Figure 2. Nigerian Conflict Deaths in 2012

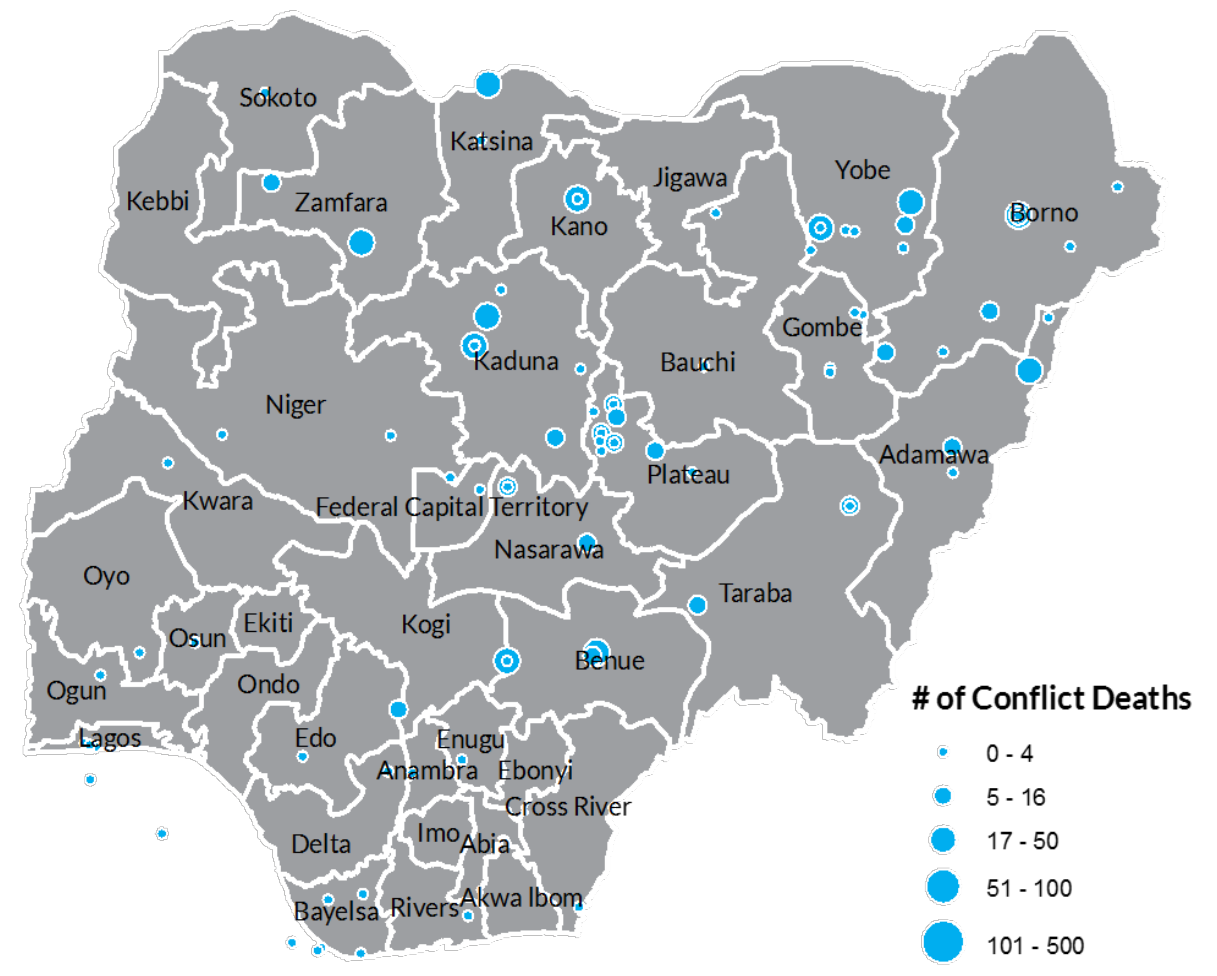

Source: Social Conflict Analysis Database (SCAD) 
Figure 3. Conceptual Framework for Infant and Child Mortality

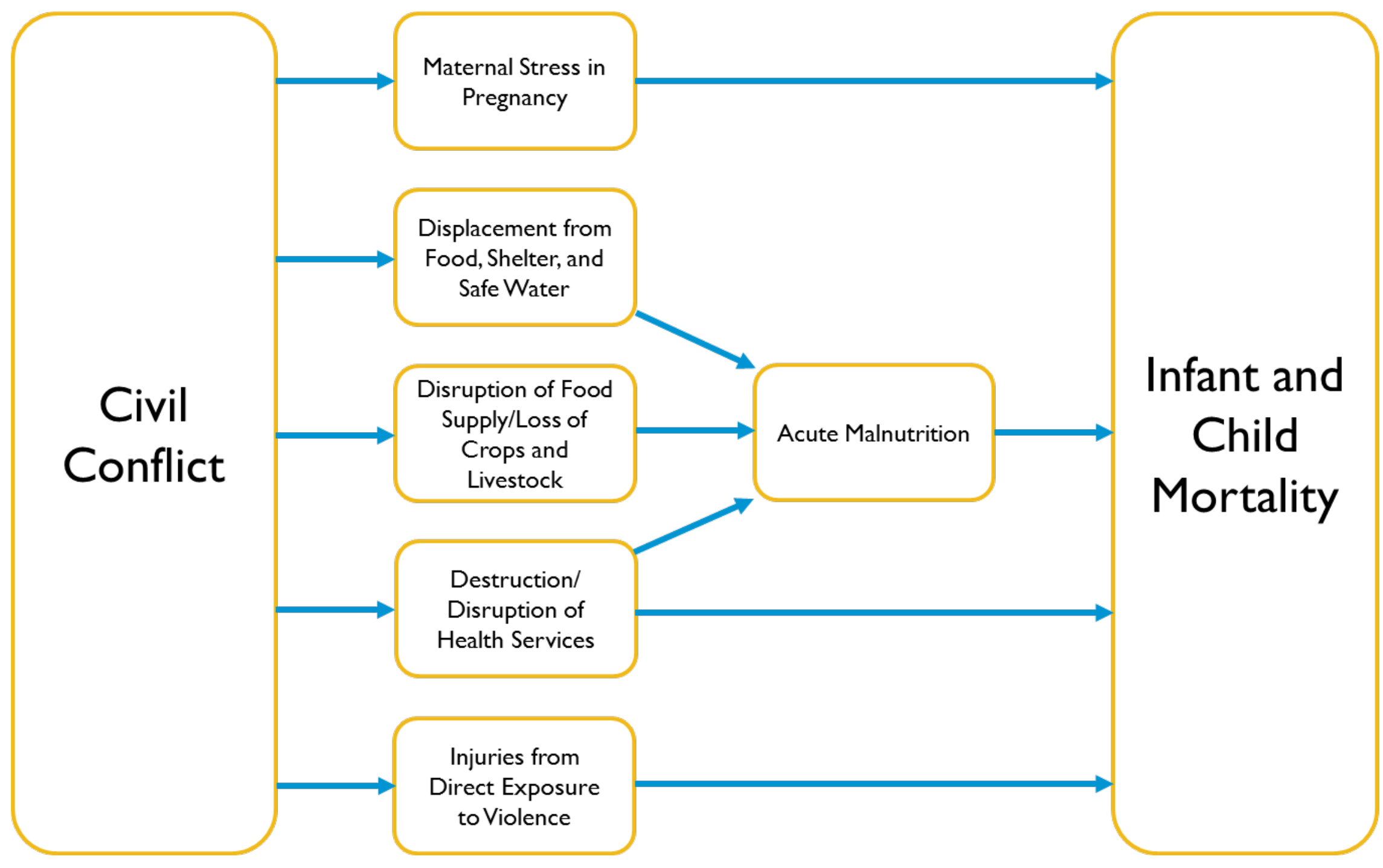


Figure 4. Wasting Z Score Distributions for Urban and Rural Children by Presence of Conflict, Nigeria, $2013^{3}$
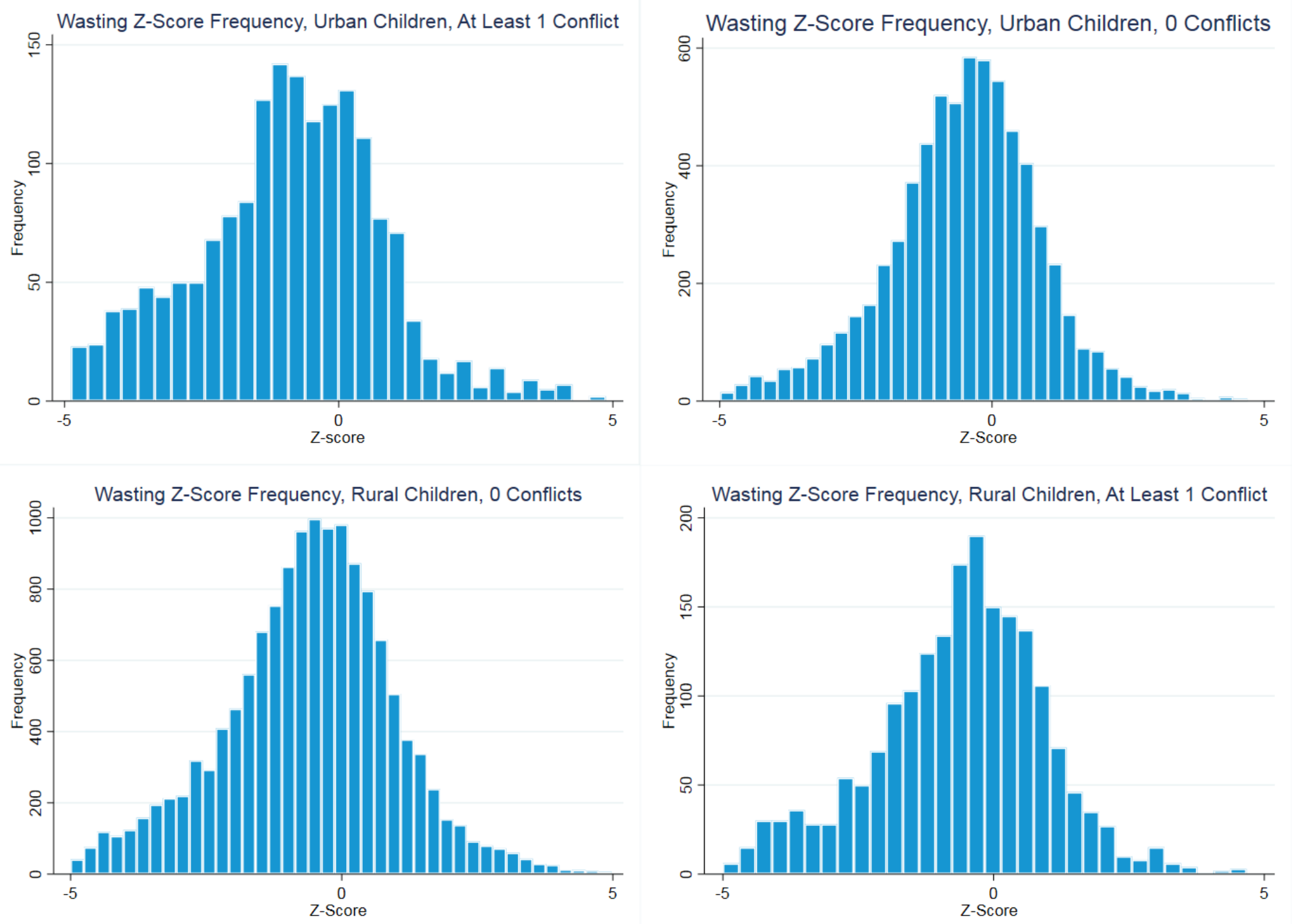

${ }^{3}$ Sources: Nigerian Demographic and Heath Survey, 2013, and Social Conflict Analysis Database (SCAD). 
Table 1. Summary of Findings from Empirical Studies of the Effect of Conflict on Mothers and Children

\begin{tabular}{|c|c|c|c|c|}
\hline Citation & Countries & Dates of Study & Key Findings & Study Limitations \\
\hline \multicolumn{5}{|c|}{ African Countries } \\
\hline Guha-Sapir et al., 2005 & $\begin{array}{l}\text { Angola, DRC, } \\
\text { Ethiopia, Sudan }\end{array}$ & $2000-2004$ & $\begin{array}{l}\text { In all countries, the conflict zones experienced higher child } \\
\text { mortality and acute malnutrition than nationally. }\end{array}$ & $\begin{array}{l}\text { Used aggregate data from a variety of surveys and } \\
\text { populations; not nationally representative. }\end{array}$ \\
\hline Avogo and Agadjanian, 2010 & Angola & 2004 & $\begin{array}{l}\text { Child mortality was twice as high if the child experienced } \\
\text { war-related forced migration in the previous year. }\end{array}$ & Sample limited to two urban municipalities. \\
\hline Verwimp, 2012 & Burundi & 1998-2007 & $\begin{array}{l}\text { Children exposed to civil war in their area of residence had a } \\
10 \% \text { increase in the probability of dying. }\end{array}$ & Small sample size ( $N=283$, only 75 exposed to civil war). \\
\hline Dabalen and Paul, 2014 & Cote d'Ivoire & $2002-2008$ & $\begin{array}{l}\text { Households in departments with at least one conflict event } \\
\text { were more food insecure. Outcomes were worse for } \\
\text { households with women and children. }\end{array}$ & $\begin{array}{l}\text { No measure of intensity of conflict exposure (e.g., } \\
\text { duration or deaths). }\end{array}$ \\
\hline Minoiu and Shemyakina, 2014 & Cote d'Ivoire & $2002-2008$ & $\begin{array}{l}\text { Children in conflict zones had significantly lower height-for- } \\
\text { age scores. }\end{array}$ & $\begin{array}{l}\text { Conflict exposure measured by living in a conflict region; } \\
\text { no measure of conflict intensity. }\end{array}$ \\
\hline Lindskog, 2016 & DRC & $2007-2014$ & $\begin{array}{l}\text { Post-neonatal mortality was highest where conflict events } \\
\text { and deaths were extremely high. Neonatal mortality was not } \\
\text { affected by conflict levels. }\end{array}$ & Conflict levels measured at the province level. \\
\hline Coghlan et al., 2006 & $\mathrm{DRC}$ & 2003-2004 & $\begin{array}{l}\text { The under- } 5 \text { mortality rate was twice as high in health zones } \\
\text { reporting violence as in health zones not reporting violence. }\end{array}$ & $\begin{array}{l}5 \text { million people could not be included in population } \\
\text { sampled due to security issues. }\end{array}$ \\
\hline $\begin{array}{l}\text { Akresh, Lucclhetti, and } \\
\text { Thirumurthy, } 2012\end{array}$ & $\begin{array}{l}\text { Eritrea and } \\
\text { Ethiopia }\end{array}$ & 2002 & $\begin{array}{l}\text { War-exposed children had } 22 \% \text { lower height-for-age scores } \\
\text { than non-war exposed children. }\end{array}$ & Conflict exposure measured by living in a conflict region. \\
\hline Delbiso et al., 2017 & Ethiopia & $2000-2013$ & $\begin{array}{l}\text { Weight-for-height (wasting) was lowest in drought-prone } \\
\text { areas. Conflict events did not have a significant impact on } \\
\text { wasting after controlling for drought. }\end{array}$ & $\begin{array}{l}\text { Used aggregate data from a variety of surveys and } \\
\text { populations; no measure of conflict intensity. }\end{array}$ \\
\hline \multicolumn{5}{|c|}{ Other Countries } \\
\hline Mashal et al., 2008 & Afghanistan & 2006 & $\begin{array}{l}\text { Internal displacement was associated with low weight-for-age } \\
\text { in children. }\end{array}$ & $\begin{array}{l}\text { Sample restricted to two urban districts; no direct measure } \\
\text { of conflict exposure. }\end{array}$ \\
\hline $\begin{array}{l}\text { Skokic, Mratovic, and Rodoja, } \\
2006\end{array}$ & $\begin{array}{l}\text { Bosnia and } \\
\text { Herzegovina }\end{array}$ & $1988-2003$ & $\begin{array}{l}\text { Perinatal and maternal mortality were higher during the war, } \\
\text { mainly due to limited access to health services. }\end{array}$ & $\begin{array}{l}\text { Sample restricted to mothers delivering in one canton. No } \\
\text { adjustment for maternal or household characteristics. }\end{array}$ \\
\hline Ascherio et al., 1992 & Iraq & 1991 & $\begin{array}{l}\text { Age-adjusted child mortality rates were } 3 \text { times as high after } \\
\text { the Gulf War in } 1991 \text { than before the war. }\end{array}$ & No measure of intensity of conflict exposure. \\
\hline Guerrero-Sedan, 2009 & Iraq & $2000-2006$ & $\begin{array}{l}\text { Children born in the highest intensity conflict provinces } \\
\text { during the Iraq war of } 2003 \text { were } .8 \mathrm{~cm} \text { shorter than children } \\
\text { born in low conflict provinces. }\end{array}$ & $\begin{array}{l}\text { Conflict exposure measured by living in a conflict region } \\
\text { or district. }\end{array}$ \\
\hline Savitz et al., 1993 & Vietnam & 1960-1988 & $\begin{array}{l}\text { Post-neonatal mortality increased significantly during the war. } \\
\text { Neonatal mortality and childhood mortality did not change } \\
\text { significantly during the war. There was no increase in infant } \\
\text { or child mortality after the war. }\end{array}$ & No measure of intensity of conflict exposure. \\
\hline
\end{tabular}


Table 2. Characteristics of Mothers and Children in Child Wasting Sample, Nigeria, 2013

\begin{tabular}{|c|c|c|}
\hline & Urban & Rural \\
\hline \multicolumn{3}{|l|}{ Child characteristics } \\
\hline Birth order (continuous) & 3.6 & 4.1 \\
\hline Gender (male) & $49.5 \%$ & $49.5 \%$ \\
\hline Preceding birth interval (months) & 37.9 & 36.4 \\
\hline \multicolumn{3}{|l|}{ Mother characteristic } \\
\hline Age at child's birth (continuous months) & 28.4 & 27.2 \\
\hline \multicolumn{3}{|l|}{ Education } \\
\hline No education & $21.1 \%$ & $61.7 \%$ \\
\hline Primary school & $21.6 \%$ & $18.6 \%$ \\
\hline Secondary school & $44.4 \%$ & $17.4 \%$ \\
\hline Higher than secondary school & $12.9 \%$ & $2.2 \%$ \\
\hline Not Married & $4.3 \%$ & $3.4 \%$ \\
\hline \multicolumn{3}{|l|}{ Household characteristics } \\
\hline Household Size & 6.6 & 7.4 \\
\hline \multicolumn{3}{|l|}{ Wealth } \\
\hline Poorest & $3.0 \%$ & $33.5 \%$ \\
\hline Poorer & $6.6 \%$ & $30.9 \%$ \\
\hline Middle & $16.0 \%$ & $21.0 \%$ \\
\hline Richer & $32.3 \%$ & $10.9 \%$ \\
\hline Richest & $42.1 \%$ & $3.7 \%$ \\
\hline \multicolumn{3}{|l|}{ Ethnicity } \\
\hline Hausa/Fulani & $26.9 \%$ & $50.2 \%$ \\
\hline Igbo/Ig & $23.3 \%$ & $4.8 \%$ \\
\hline Yoruba & $25.4 \%$ & $4.5 \%$ \\
\hline Other & $24.3 \%$ & $40.5 \%$ \\
\hline \multicolumn{3}{|l|}{ Region } \\
\hline North Central & $8.9 \%$ & $18.0 \%$ \\
\hline North East & $11.5 \%$ & $20.2 \%$ \\
\hline North West & $23.4 \%$ & $41.3 \%$ \\
\hline South East & $17.5 \%$ & $4.2 \%$ \\
\hline South South & $8.9 \%$ & $9.5 \%$ \\
\hline South West & $29.8 \%$ & $6.8 \%$ \\
\hline $\mathbf{N}$ & 8,507 & 15,961 \\
\hline
\end{tabular}

Note: Samples for infant and child mortality analyses are different, but sample characteristics are not significantly different. For infant Mortality, $\mathrm{N}=18,171$ (urban) and 38,838 (rural). For child mortality, $\mathrm{N}=9,369$ (urban) and 20,049 (rural).

Source: Nigerian Demographic and Health Survey, 2013 
Table 3. Child Wasting (ages 0-4), Infant Mortality, and Child Mortality (ages 1-4)

Nigeria, 2013

\begin{tabular}{|c|c|c|c|}
\hline & Child Wasting & Infant Mortality* & Child Mortality* \\
\hline Total & $19.2 \%$ & 77 & 69 \\
\hline Urban & $19.0 \%$ & 60 & 39 \\
\hline Rural & $19.3 \%$ & 85 & 84 \\
\hline
\end{tabular}

*Per 1000

Source: Nigerian Demographic and Health Survey, 2013 
Table 4. Average Annual Exposure to Conflicts by Study and Study Period

\begin{tabular}{|c|c|c|c|c|c|c|}
\hline & \multicolumn{2}{|c|}{$\begin{array}{l}\text { Previous Year Exposure } \\
\text { for Child Wasting: } 2012\end{array}$} & \multicolumn{2}{|c|}{$\begin{array}{l}\text { Prenatal Exposure for } \\
\text { Infant Mortality: } \\
\text { 2002-2012 }\end{array}$} & \multicolumn{2}{|c|}{$\begin{array}{l}\text { First Year of Life } \\
\text { Exposure for } \\
\text { Child Mortality: } \\
\text { 2003-2009 }\end{array}$} \\
\hline & Urban & Rural & Urban & Rural & Urban & Rural \\
\hline \multicolumn{7}{|l|}{$\begin{array}{l}\text { Average annual exposure to conflicts } \\
\text { by type (unweighted) }\end{array}$} \\
\hline Demonstration $^{1}$ or strike ${ }^{2}$ & 0.62 & 0.08 & 0.36 & 0.06 & 0.43 & 0.08 \\
\hline Violent riot ${ }^{3}$ & 0.13 & 0.04 & 0.19 & 0.07 & 0.24 & 0.08 \\
\hline Internal governmental violence ${ }^{4}$ & 1.82 & 0.46 & 0.14 & 0.03 & 0.12 & 0.03 \\
\hline External governmental violence ${ }^{5}$ & 1.75 & 0.45 & 0.10 & 0.04 & 0.05 & 0.02 \\
\hline $\begin{array}{l}\text { Average annual total conflicts during } \\
\text { exposure period (unweighted) }\end{array}$ & 4.32 & 1.04 & 0.79 & 0.20 & 0.84 & 0.20 \\
\hline $\begin{array}{l}\text { Average annual conflict deaths } \\
\text { (unweighted) }\end{array}$ & 8.94 & 2.43 & 6.39 & 1.67 & 5.69 & 1.74 \\
\hline $\begin{array}{l}\text { Average annual length of conflict } \\
\text { (days, unweighted) }\end{array}$ & 11.85 & 3.08 & 0.80 & 0.38 & 0.82 & 0.42 \\
\hline $\begin{array}{l}\text { Average annual conflict deaths } \\
\text { (weighted) }\end{array}$ & 1.83 & 0.14 & 1.40 & 0.09 & 1.26 & 0.10 \\
\hline $\begin{array}{l}\text { Average annual length of conflict } \\
\text { (days, weighted) }\end{array}$ & 2.78 & 0.16 & 0.15 & 0.02 & 0.15 & 0.03 \\
\hline
\end{tabular}

1. Demonstration: Peaceful action directed towards members of another group or government authorities

2. Strike: Engaging in abandonment of workplaces and public facilities

3. Violent riot: Violent action directed toward members of another group or government authorities

4. Internal governmental violence: Violence waged against government authorities, by government authorities, or within the government itself

5. External governmental violence: Violence waged by non-state groups without government actors or targets

Source: Social Conflict Analysis Database (SCAD). 
Table 5. Odds Ratios from Logistic Regressions Predicting Risk of Child Wasting: Ages 0-4, Nigeria, 2012

\begin{tabular}{|c|c|c|c|c|}
\hline \multirow{2}{*}{ Control Variables } & \multicolumn{2}{|c|}{ Deaths from Conflicts } & \multicolumn{2}{|c|}{ Days of Conflicts } \\
\hline & Urban & Rural & Urban & Rural \\
\hline Conflict deaths weighted by distance (continuous) & $1.05^{* * *}$ & $1.17^{*}$ & -- & --- \\
\hline Conflict days weighted by distance (continuous) & -- & -- & $1.04^{* * *}$ & $1.13^{* *}$ \\
\hline Preceding birth interval (continuous) & 0.999 & 1.001 & 1.000 & 1.001 \\
\hline Birth order (continuous) & 1.02 & 0.97 & 1.02 & 0.97 \\
\hline Child gender (male) & $1.29 * * *$ & 1.07 & $1.28^{* * *}$ & 1.07 \\
\hline Mother's age at child's birth (continuous years) & 0.99 & 1.01 & 0.99 & 1.01 \\
\hline \multicolumn{5}{|l|}{ Mother's highest education level } \\
\hline No education (Reference) & 1 & 1 & 1 & 1 \\
\hline Any primary school & 0.99 & $0.80 * *$ & 0.97 & $0.81 * *$ \\
\hline Any secondary school & 0.88 & $0.70^{* * *}$ & 0.84 & $0.70^{* * *}$ \\
\hline Higher than secondary school & $0.62^{* *}$ & $0.58^{*}$ & $0.60^{* * *}$ & $0.58^{*}$ \\
\hline Mother not married & 0.98 & $0.72^{* *}$ & 0.98 & $0.72^{* *}$ \\
\hline Number of household members (continuous) & 0.998 & 0.999 & 0.996 & 1.00 \\
\hline \multicolumn{5}{|l|}{ Ethnicity } \\
\hline Hausa/Fulani (Reference) & 1 & 1 & 1 & 1 \\
\hline Igbo/Ig & 1.39 & 0.61 & $1.61 *$ & 0.61 \\
\hline Yoruba & 1.36 & $0.51^{* *}$ & $1.57^{* *}$ & $0.51^{* *}$ \\
\hline Other & $1.57^{* *}$ & 0.84 & $1.75^{* * *}$ & 0.85 \\
\hline \multicolumn{5}{|l|}{ Region } \\
\hline North Central & $0.23^{* * *}$ & $0.65^{* * *}$ & $0.23^{* * *}$ & $0.68^{* * *}$ \\
\hline North East & $0.30^{* * *}$ & 0.97 & $0.40^{* * *}$ & 0.99 \\
\hline North West (Reference) & 1 & 1 & 1 & 1 \\
\hline South East & $0.24^{* * *}$ & 1.02 & $0.23^{* * *}$ & 1.04 \\
\hline South South & $0.19 * * *$ & $0.67 * * *$ & $0.19 * * *$ & $0.66^{* * *}$ \\
\hline South West & $0.23^{* * *}$ & $0.54 * * *$ & $0.21 * * *$ & $0.54^{* * *}$ \\
\hline $\mathbf{N}$ & 8,507 & 15,961 & 8,507 & 15,961 \\
\hline
\end{tabular}

1. ${ }^{* * *}: \mathrm{p}<.01 ; * * \mathrm{p}<.05 ; *: \mathrm{p}<.10$ (borderline significance)

2. Year of child's birth is also included in the regression.

Sources: Nigerian Demographic and Health Survey 2013 and Social Conflict Analysis Database (SCAD) for conflict data. 
Table 6. Coefficients from Ordinary Least Squares Regressions Predicting Child Wasting Z Score (X 100), Nigeria, 2012

\begin{tabular}{|c|c|c|c|c|}
\hline \multirow{2}{*}{ Control Variables } & \multicolumn{2}{|c|}{ Deaths from Conflicts } & \multicolumn{2}{|c|}{ Days of Conflicts } \\
\hline & Urban & Rural & Urban & Rural \\
\hline $\begin{array}{l}\text { Conflict deaths weighted by distance } \\
\text { (continuous) }\end{array}$ & $-5.97 * * *$ & $-13.12^{*}$ & -- & -- \\
\hline $\begin{array}{l}\text { Conflict days weighted by distance } \\
\text { (continuous) }\end{array}$ & -- & -- & $-3.83^{* * *}$ & $-10.92^{* *}$ \\
\hline Preceding birth interval (continuous) & -0.08 & -0.040 & -0.08 & -0.040 \\
\hline Birth order (continuous) & -2.1 & $3.03^{* *}$ & -2.05 & $2.93 * *$ \\
\hline Child gender (male) & $-10.86^{* *}$ & -2.95 & $-10.06^{* *}$ & -2.82 \\
\hline Mother's age at child's birth (continuous) & 0.29 & $-0.86^{*}$ & 0.46 & $-0.84 *$ \\
\hline \multicolumn{5}{|l|}{ Mother's highest education level } \\
\hline No education & 0 & 0 & 0 & 0 \\
\hline Primary school & -3.61 & $13.95^{* *}$ & -2.45 & $13.49 * *$ \\
\hline Secondary school & -0.05 & 8.18 & 2.47 & 7.34 \\
\hline Higher than secondary school & $21.31 *$ & $26.78^{*}$ & $22.70 * *$ & $26.75^{*}$ \\
\hline Mother not married & 5.47 & 9.21 & 5.68 & 9.2 \\
\hline Number household members (continuous) & -0.120 & $-1.19^{*}$ & 0.080 & $-1.22 * *$ \\
\hline \multicolumn{5}{|l|}{ Ethnicity } \\
\hline Hausa/Fulani (ref) & 0 & 0 & 0 & 0 \\
\hline $\operatorname{Igbo} / \operatorname{Ig}$ & $-30.80 * *$ & 16.31 & $-40.67^{* * *}$ & 16.96 \\
\hline Yoruba & $-26.09 * *$ & $40.09 * * *$ & $-37.09 * * *$ & $39.93 * * *$ \\
\hline Other & $-28.27 * *$ & $26.90 * * *$ & $-36.84 * * *$ & $25.77 * * *$ \\
\hline \multicolumn{5}{|l|}{ Region } \\
\hline North Central & $84.38^{* * *}$ & 0.67 & $83.03^{* * *}$ & -2.18 \\
\hline North East & $80.38^{* * *}$ & $-14.02^{*}$ & $50.27 * * *$ & $-15.91 *$ \\
\hline North West (ref) & 0 & 0 & 0 & 0 \\
\hline South East & $80.42^{* * *}$ & -2.57 & $80.64 * * *$ & -3.9 \\
\hline South South & $91.86^{* * *}$ & -6.36 & $91.99 * * *$ & -5.9 \\
\hline South West & $69.16^{* * *}$ & -4.23 & $73.53^{* * *}$ & -4.74 \\
\hline $\mathbf{N}$ & 8,507 & 15,961 & 8,507 & 15,961 \\
\hline
\end{tabular}

1. ${ }^{* * *}: \mathrm{p}<.01 ; * * \mathrm{p}<.05 ; *: \mathrm{p}<.10$ (borderline significance)

2. Year of child birth is also included as a control variable

Sources: Nigerian Demographic and Health Survey 2013 and Social Conflict Analysis Database (SCAD) for conflict data. 
Table 7. Odds Ratios from Results of Additional Logistic Regression Analyses

\begin{tabular}{|l|l|l|l|l|}
\hline & \multicolumn{4}{c|}{ Odds Ratio for Conflict Measure } \\
\hline Regressions Predicting: & \multicolumn{2}{|c|}{ Deaths from Conflicts } & \multicolumn{2}{c|}{ Days of Conflicts } \\
\hline & Urban & Rural & Urban & Rural \\
\hline Wasting (with wealth index) & $1.05^{* * *}$ & $1.17^{*}$ & $1.04^{* * *}$ & $1.13^{* * *}$ \\
\hline Wasting (without Northeast Region) & $1.08^{* * *}$ & $1.21^{* *}$ & $1.04^{* * *}$ & $1.13^{* *}$ \\
\hline Infant Mortality: Model 1 & $1.01^{*}$ & 0.98 & 1.01 & 0.94 \\
\hline Infant Mortality: Model 2 & 1.01 & 0.98 & 1.01 & 0.94 \\
\hline Child Mortality (1-4): Model 1 & 0.99 & 1.02 & 1.02 & 0.99 \\
\hline Child Mortality (1-4): Model 2 & 0.98 & 1.02 & 1.02 & 0.999 \\
\hline
\end{tabular}

Note: ${ }^{* *}: \mathrm{p}<.01 ; * *: \mathrm{p}<.05 ; *: \mathrm{p}<.10$ (borderline significance); see Appendix Tables 1-4 for detail.

Sources: Nigerian Demographic and Health Survey 2013 and Social Conflict Analysis Database (SCAD) for conflict data. 

(As Table 5 but Including Wealth Index)

\begin{tabular}{|c|c|c|c|c|}
\hline \multirow{2}{*}{ Control Variables } & \multicolumn{2}{|c|}{ Deaths from Conflicts } & \multicolumn{2}{|c|}{ Days of Conflicts } \\
\hline & Urban & Rural & Urban & Rural \\
\hline $\begin{array}{l}\text { Conflict deaths weighted by distance } \\
\text { (continuous) }\end{array}$ & $1.05^{* * *}$ & $1.17^{*}$ & ---- & ---- \\
\hline $\begin{array}{l}\text { Conflict days weighted by distance } \\
\text { (continuous) }\end{array}$ & ---- & ---- & $1.04 * * *$ & $1.13^{* *}$ \\
\hline Preceding birth interval (continuous) & 0.999 & 1.001 & 1.000 & 1.001 \\
\hline Birth order (continuous) & 1.02 & 0.97 & 1.02 & 0.97 \\
\hline Child gender (male) & $1.29 * * *$ & 1.07 & $1.28^{* * *}$ & 1.07 \\
\hline Mother's age at birth (continuous) & 0.99 & 1.01 & 0.99 & 1.01 \\
\hline \multicolumn{5}{|l|}{ Mother's highest education level } \\
\hline No education (reference) & 1 & 1 & 1 & 1 \\
\hline Any primary school & 0.97 & $0.81 * *$ & 0.95 & $0.81 * *$ \\
\hline Any secondary school & 0.84 & $0.71 * * *$ & $0.80 *$ & $0.72^{* * *}$ \\
\hline Higher than secondary school & $0.59 * * *$ & 0.62 & $0.56^{* * *}$ & 0.63 \\
\hline Mother not married & 0.99 & $0.71 * *$ & 0.99 & $0.71 * *$ \\
\hline $\begin{array}{l}\text { Number household members } \\
\text { (continuous) }\end{array}$ & 0.997 & 1.000 & 0.995 & 1.000 \\
\hline \multicolumn{5}{|l|}{ Wealth } \\
\hline Poorest (Reference) & 1 & 1 & 1 & 1 \\
\hline Poorer & 0.93 & 1.03 & 0.91 & 1.02 \\
\hline Middle & 1.13 & 0.995 & 1.12 & 0.99 \\
\hline Richer & 1.13 & 0.94 & 1.11 & 0.93 \\
\hline Richest & 1.19 & 0.87 & 1.17 & 0.86 \\
\hline \multicolumn{5}{|l|}{ Ethnicity } \\
\hline Hausa/Fulani (Reference) & 1 & 1 & 1 & 1 \\
\hline $\mathrm{Igbo} / \mathrm{Ig}$ & 1.38 & 0.62 & $1.60 *$ & 0.62 \\
\hline Yoruba & 1.36 & $0.52^{* *}$ & $1.57^{* *}$ & $0.52 * *$ \\
\hline Other & $1.57 * *$ & 0.84 & $1.74 * * *$ & 0.85 \\
\hline \multicolumn{5}{|l|}{ Region } \\
\hline North Central & $0.22 * * *$ & $0.66^{* * *}$ & $0.22 * * *$ & $0.69 * * *$ \\
\hline North East & $0.30^{* * *}$ & 0.97 & $0.40^{* * *}$ & 0.996 \\
\hline North West (Reference) & 1 & 1 & 1 & 1 \\
\hline South East & $0.25^{* * *}$ & 1.04 & $0.24 * * *$ & 1.07 \\
\hline South South & $0.19 * * *$ & $0.69 * *$ & $0.19 * * *$ & $0.69 * *$ \\
\hline South West & $0.22 * * *$ & $0.54 * * *$ & $0.21 * * *$ & $0.55^{* * *}$ \\
\hline $\mathbf{N}$ & 8,507 & 15,961 & 8,507 & 15,961 \\
\hline
\end{tabular}

1. ${ }^{* * *}: \mathrm{p}<.01 ; * *: \mathrm{p}<.05 ; *: \mathrm{p}<.10$ (borderline significance)

2. Year of child's birth is also included in the regression.

Sources: Nigerian Demographic and Health Survey 2013 and Social Conflict Analysis Database (SCAD) for conflict data. 
Appendix Table 2. Odds Ratios from Logistic Regressions Predicting Risk of Child Wasting, Nigeria 2012 (As Table 5 Without Northeast Region)

\begin{tabular}{|c|c|c|c|c|}
\hline \multirow{2}{*}{ Control Variables } & \multicolumn{2}{|c|}{ Deaths from Conflicts } & \multicolumn{2}{|c|}{ Days of Conflicts } \\
\hline & Urban & Rural & Urban & Rural \\
\hline $\begin{array}{l}\text { Conflict deaths weighted by distance } \\
\text { (continuous) }\end{array}$ & $1.08^{* * *}$ & $1.21 * *$ & ---- & ---- \\
\hline $\begin{array}{l}\text { Conflict days weighted by distance } \\
\text { (continuous) }\end{array}$ & ---- & ---- & $1.04^{* * *}$ & $1.13^{* *}$ \\
\hline Preceding birth interval (continuous) & 0.999 & 1.002 & 0.999 & 1.002 \\
\hline Birth order (continuous) & 0.997 & $0.96^{*}$ & 1.000 & 0.96 \\
\hline Child gender & $1.23^{* * *}$ & 1.07 & $1.23^{* * *}$ & 1.07 \\
\hline Mother's age at birth & 0.999 & 1.01 & 0.998 & 1.01 \\
\hline \multicolumn{5}{|l|}{ Mother's highest education level } \\
\hline No education (reference) & 1 & 1 & 1 & 1 \\
\hline Any primary school & 1.01 & 0.89 & 1.02 & 0.90 \\
\hline Any secondary school & 0.9 & $0.77 * *$ & 0.92 & $0.78^{* *}$ \\
\hline Higher than secondary school & $0.64 * *$ & 0.58 & $0.65^{* *}$ & 0.59 \\
\hline Mother not married & 1.01 & $0.72 * *$ & 1.02 & $0.72 * *$ \\
\hline Number household members (continuous) & 0.996 & 1.01 & 0.995 & 1.01 \\
\hline \multicolumn{5}{|l|}{ Ethnicity } \\
\hline Hausa/Fulani (ref) & 1 & 1 & 1 & 1 \\
\hline $\mathrm{Igbo} / \mathrm{Ig}$ & $1.59 *$ & 0.67 & $1.79 *$ & 0.67 \\
\hline Yoruba & $1.60 * *$ & $0.51 * *$ & $1.77 * *$ & $0.51 * *$ \\
\hline Other & $1.91 * * *$ & 0.87 & $2.06^{* * *}$ & 0.88 \\
\hline \multicolumn{5}{|l|}{ Region } \\
\hline North Central & $0.21 * * *$ & $0.61 * * *$ & $0.19 * * *$ & $0.63^{* * *}$ \\
\hline North West (ref) & 1 & 1 & 1 & 1 \\
\hline South East & $0.24 * * *$ & 0.87 & $0.21^{* * *}$ & 0.88 \\
\hline South South & $0.18^{* * *}$ & $0.60^{* * *}$ & $0.16^{* * *}$ & $0.59 * * *$ \\
\hline South West & $0.21 * * *$ & $0.51 * * *$ & $0.18^{* * *}$ & $0.51^{* * *}$ \\
\hline $\mathbf{N}$ & 7,433 & 12,150 & 7,433 & 12,150 \\
\hline
\end{tabular}

1. ${ }^{* * *}: \mathrm{p}<.01 ; * * \mathrm{p}<.05 ; *: \mathrm{p}<.10$ (borderline significance)

2. Exposure for infant mortality is prenatal; exposure for child mortality is age one; exposure for child wasting is 2012

3. Additional control variables included in the regression are year of birth

Sources: Nigerian Demographic and Health Survey 2013 and Social Conflict Analysis Database (SCAD) for conflict data. 
Appendix Table 3. Odds Ratios from Logistic Regressions Predicting Risk of Infant Death, Nigeria 2002-2012

\begin{tabular}{|c|c|c|c|c|c|c|c|c|}
\hline \multirow{3}{*}{ Control Variables } & \multicolumn{4}{|c|}{ With Wealth Index } & \multicolumn{4}{|c|}{ Without Wealth Index } \\
\hline & \multicolumn{2}{|c|}{$\begin{array}{l}\text { Deaths from } \\
\text { Conflicts }\end{array}$} & \multicolumn{2}{|c|}{ Days of Conflicts } & \multicolumn{2}{|c|}{$\begin{array}{l}\text { Deaths from } \\
\text { Conflicts }\end{array}$} & \multicolumn{2}{|c|}{ Days of Conflicts } \\
\hline & Urban & Rural & Urban & Rural & Urban & Rural & Urban & Rural \\
\hline $\begin{array}{l}\text { Conflict deaths weighted by } \\
\text { distance (continuous) }\end{array}$ & $1.01 *$ & 0.98 & ---- & ---- & 1.01 & 0.98 & ---- & ---- \\
\hline $\begin{array}{l}\text { Conflict days weighted by } \\
\text { distance (continuous) }\end{array}$ & ---- & ---- & 1.01 & 0.94 & ---- & ---- & 1.01 & 0.94 \\
\hline $\begin{array}{l}\text { Preceding birth interval } \\
\text { (continuous) }\end{array}$ & $0.98^{* * *}$ & $0.97 * * *$ & $0.98^{* * *}$ & $0.97 * * *$ & $0.98^{* * *}$ & $0.97 * * *$ & $0.98^{* * *}$ & $0.97 * * *$ \\
\hline Birth order & $1.14^{* * *}$ & $1.15^{* * *}$ & $1.14^{* * *}$ & $1.15^{* * *}$ & $1.15^{* * *}$ & $1.15^{* * *}$ & $1.15^{* * *}$ & $1.15^{* * *}$ \\
\hline Child gender (male) & $1.47^{* * *}$ & $1.13^{* * *}$ & $1.47^{* * *}$ & $1.13^{* * *}$ & $1.47^{* * *}$ & $1.13^{* * *}$ & $1.47^{* * *}$ & $1.13^{* * *}$ \\
\hline Mother's age at birth & 1.004 & $0.98^{* * *}$ & 1.004 & $0.98^{* * *}$ & 1.002 & $0.98^{* * *}$ & 1.002 & $0.98^{* * *}$ \\
\hline \multicolumn{9}{|l|}{ Mother's highest education level } \\
\hline No education (reference) & 1 & 1 & 1 & 1 & 1 & 1 & 1 & 1 \\
\hline Any primary school & 0.84 & 0.94 & 0.84 & 0.94 & $0.79 *$ & 0.95 & $0.80^{*}$ & 0.95 \\
\hline Any secondary school & $0.73^{* *}$ & 0.87 & $0.73 * *$ & 0.87 & $0.63^{* * *}$ & 0.87 & $0.64 * * *$ & 0.87 \\
\hline Higher than secondary school & 0.76 & 0.84 & 0.76 & 0.84 & $0.64 * *$ & 0.76 & $0.64 * *$ & 0.76 \\
\hline Mother not married & 1.18 & $1.35^{* *}$ & 1.18 & $1.35^{* *}$ & 1.20 & $1.37 * *$ & 1.21 & $1.37 * *$ \\
\hline Number household members & $0.87^{* * *}$ & $0.92^{* * *}$ & $0.87^{* * *}$ & $0.92^{* * *}$ & $0.87 * * *$ & $0.92 * * *$ & $0.87^{* * *}$ & $0.92 * * *$ \\
\hline \multicolumn{9}{|l|}{ Wealth } \\
\hline Poorest (Reference) & 1 & 1 & 1 & 1 & $\mathrm{~N} / \mathrm{A}$ & $\mathrm{N} / \mathrm{A}$ & $\mathrm{N} / \mathrm{A}$ & $\mathrm{N} / \mathrm{A}$ \\
\hline Poorer & 0.95 & 1.09 & 0.95 & 1.09 & $\mathrm{~N} / \mathrm{A}$ & $\mathrm{N} / \mathrm{A}$ & $\mathrm{N} / \mathrm{A}$ & $\mathrm{N} / \mathrm{A}$ \\
\hline Middle & $0.72 *$ & 0.98 & $0.72 *$ & 0.98 & $\mathrm{~N} / \mathrm{A}$ & $\mathrm{N} / \mathrm{A}$ & $\mathrm{N} / \mathrm{A}$ & $\mathrm{N} / \mathrm{A}$ \\
\hline Richer & $0.73^{*}$ & 1.14 & 0.74 & 1.14 & $\mathrm{~N} / \mathrm{A}$ & $\mathrm{N} / \mathrm{A}$ & $\mathrm{N} / \mathrm{A}$ & $\mathrm{N} / \mathrm{A}$ \\
\hline Richest & $0.62^{* *}$ & 0.74 & $0.63 * *$ & 0.74 & $\mathrm{~N} / \mathrm{A}$ & $\mathrm{N} / \mathrm{A}$ & $\mathrm{N} / \mathrm{A}$ & $\mathrm{N} / \mathrm{A}$ \\
\hline \multicolumn{9}{|l|}{ Ethnicity } \\
\hline Hausa/Fulani (Reference) & 1 & 1 & 1 & 1 & 1 & 1 & 1 & 1 \\
\hline $\mathrm{Igbo} / \mathrm{Ig}$ & 0.62 & 0.82 & $0.61 *$ & 0.82 & 0.62 & 0.82 & 0.62 & 0.82 \\
\hline Yoruba & $0.66^{*}$ & 1.07 & $0.66^{* *}$ & 1.07 & $0.68^{*}$ & 1.05 & $0.67 *$ & 1.05 \\
\hline Other & $0.70^{* *}$ & 0.88 & $0.70^{* *}$ & 0.88 & $0.71 * *$ & 0.88 & $0.71 * *$ & 0.88 \\
\hline \multicolumn{9}{|l|}{ Region } \\
\hline North Central & $1.38^{*}$ & $0.82 *$ & $1.39 *$ & $0.82 *$ & 1.33 & $0.81 *$ & 1.33 & $0.81 *$ \\
\hline North East & 1.26 & $0.87 *$ & 1.25 & $0.87^{*}$ & 1.25 & $0.86^{*}$ & 1.24 & $0.86^{*}$ \\
\hline North West (Reference) & 1 & 1 & 1 & 1 & 1 & 1 & 1 & 1 \\
\hline South East & $2.16^{* *}$ & 1.03 & $2.13^{* *}$ & 1.04 & $2.28^{* * *}$ & 1.03 & $2.25^{* * *}$ & 1.03 \\
\hline South South & 1.47 & $0.68^{* * *}$ & 1.44 & $0.69 * * *$ & 1.41 & $0.68^{* * *}$ & 1.39 & $0.68^{* * *}$ \\
\hline South West & $1.55^{*}$ & $0.67^{* *}$ & $1.53^{*}$ & $0.67^{* *}$ & 1.45 & $0.67^{* *}$ & 1.43 & $0.67^{* *}$ \\
\hline N Value & 18,171 & 38,838 & 18,171 & 38,838 & 18,171 & 38,838 & 18,171 & 38,838 \\
\hline
\end{tabular}

1. ${ }^{* * *}: \mathrm{p}<.01 ; * *: \mathrm{p}<.05 ; *: \mathrm{p}<.10$ (borderline significance)

2. Year of child's birth is also included in the regression.

Sources: Nigerian Demographic and Health Survey 2013 and Social Conflict Analysis Database (SCAD) for conflict data. 


\begin{tabular}{|c|c|c|c|c|c|c|c|c|}
\hline \multirow{3}{*}{ Control Variables } & \multicolumn{4}{|c|}{ With Wealth Index } & \multicolumn{4}{|c|}{ Without Wealth Index } \\
\hline & \multicolumn{2}{|c|}{$\begin{array}{l}\text { Deaths from } \\
\text { Conflicts }\end{array}$} & \multicolumn{2}{|c|}{ Days of Conflicts } & \multicolumn{2}{|c|}{$\begin{array}{l}\text { Deaths from } \\
\text { Conflicts }\end{array}$} & \multicolumn{2}{|c|}{ Days of Conflicts } \\
\hline & Urban & Rural & Urban & Rural & Urban & Rural & Urban & Rural \\
\hline $\begin{array}{l}\text { Conflict deaths weighted by } \\
\text { distance (continuous) }\end{array}$ & 0.99 & 1.02 & ---- & ---- & 0.98 & 1.02 & ---- & --- \\
\hline $\begin{array}{l}\text { Conflict days weighted by } \\
\text { distance (continuous) }\end{array}$ & --- & --- & 1.02 & 0.99 & ---- & ----- & 1.02 & 0.999 \\
\hline $\begin{array}{l}\text { Preceding birth interval } \\
\text { (continuous) }\end{array}$ & $0.99 * * *$ & $0.98^{* * *}$ & $0.98^{* * *}$ & $0.98^{* * *}$ & $0.98^{* * *}$ & $0.98^{* * *}$ & $0.98^{* * *}$ & $0.98^{* * *}$ \\
\hline Birth order (continuous) & $1.14 * * *$ & $1.14^{* * *}$ & $1.14^{* * *}$ & $1.14 * * *$ & $1.15^{* * *}$ & $1.14^{* * *}$ & $1.16^{* * *}$ & $1.14^{* * *}$ \\
\hline Child gender (male) & 1.15 & 0.98 & 1.16 & 0.98 & 1.15 & 0.98 & 1.16 & 0.97 \\
\hline $\begin{array}{l}\text { Mother's age at birth } \\
\text { (continuous) }\end{array}$ & $0.96^{* * *}$ & $0.97 * * *$ & $0.95^{* * *}$ & $0.97 * * *$ & $0.95^{* * *}$ & $0.97 * * *$ & $0.95^{* * *}$ & $0.97^{* * *}$ \\
\hline \multicolumn{9}{|l|}{ Mother's highest education level } \\
\hline No education (Reference) & 1 & 1 & 1 & 1 & 1 & 1 & 1 & 1 \\
\hline Any primary school & $0.55^{* * *}$ & 0.95 & $0.55^{* * *}$ & 0.95 & $0.48^{* * *}$ & 0.98 & $0.48^{* * *}$ & 0.98 \\
\hline Any secondary school & $0.49 * * *$ & $0.72^{* *}$ & $0.48^{* * *}$ & $0.72 * *$ & $0.38^{* * *}$ & $0.76^{*}$ & $0.37 * * *$ & $0.76^{*}$ \\
\hline Higher than secondary school & $0.20 * * *$ & $0.39 *$ & $0.19 * * *$ & $0.39 *$ & $0.15^{* * *}$ & $0.46^{*}$ & $0.15^{* * *}$ & $0.46^{*}$ \\
\hline Mother not married & $1.54^{*}$ & 1.06 & $1.54^{*}$ & 1.06 & $1.60^{* *}$ & 1.07 & $1.60 * *$ & 1.07 \\
\hline Number household members & $0.93 * * *$ & $0.92^{* * *}$ & $0.93^{* * *}$ & $0.92^{* * *}$ & $0.93^{* * *}$ & $0.92^{* * *}$ & $0.93^{* * *}$ & $0.92^{* * *}$ \\
\hline \multicolumn{9}{|l|}{ Wealth } \\
\hline Poorest (Reference) & 1 & 1 & 1 & 1 & $\mathrm{~N} / \mathrm{A}$ & $\mathrm{N} / \mathrm{A}$ & $\mathrm{N} / \mathrm{A}$ & $\mathrm{N} / \mathrm{A}$ \\
\hline Poorer & 1.28 & $1.19 * *$ & 1.28 & $1.20 * *$ & $\mathrm{~N} / \mathrm{A}$ & $\mathrm{N} / \mathrm{A}$ & $\mathrm{N} / \mathrm{A}$ & $\mathrm{N} / \mathrm{A}$ \\
\hline Middle & 0.86 & 1.17 & 0.85 & 1.17 & $\mathrm{~N} / \mathrm{A}$ & $\mathrm{N} / \mathrm{A}$ & $\mathrm{N} / \mathrm{A}$ & $\mathrm{N} / \mathrm{A}$ \\
\hline Richer & $0.58^{* *}$ & 1.04 & $0.57 * *$ & 1.04 & $\mathrm{~N} / \mathrm{A}$ & $\mathrm{N} / \mathrm{A}$ & $\mathrm{N} / \mathrm{A}$ & $\mathrm{N} / \mathrm{A}$ \\
\hline Richest & $0.64 *$ & 1.67 & $0.62^{*}$ & 1.67 & $\mathrm{~N} / \mathrm{A}$ & $\mathrm{N} / \mathrm{A}$ & $\mathrm{N} / \mathrm{A}$ & $\mathrm{N} / \mathrm{A}$ \\
\hline \multicolumn{9}{|l|}{ Ethnicity } \\
\hline Hausa/Fulani (Reference) & 1 & 1 & 1 & 1 & 1 & 1 & 1 & 1 \\
\hline $\mathrm{Igbo} / \mathrm{Ig}$ & 1.32 & 0.75 & 1.33 & 0.74 & 1.31 & 0.78 & 1.33 & 0.78 \\
\hline Yoruba & $1.99 * *$ & $0.45^{* *}$ & $2.03^{* *}$ & $0.45^{* *}$ & $1.91 * *$ & $0.47 * *$ & $1.95^{* *}$ & $0.47 * *$ \\
\hline Other & 1.04 & $0.73^{* * *}$ & 1.06 & $0.73^{* * *}$ & 1.004 & $0.74 * * *$ & 1.03 & $0.74^{* * *}$ \\
\hline \multicolumn{9}{|l|}{ Region } \\
\hline North Central & $0.45^{* * *}$ & $0.36 * * *$ & $0.46^{* * *}$ & $0.36^{* * *}$ & $0.43^{* * *}$ & $0.36^{* * *}$ & $0.44 * * *$ & $0.36^{* * *}$ \\
\hline North East & $0.56^{* * *}$ & 0.96 & $0.57 * * *$ & 0.960 & $0.57 * * *$ & 0.94 & $0.58^{* * *}$ & 0.940 \\
\hline North West (Reference) & 1 & 1 & 1 & 1 & 1 & 1 & 1 & 1 \\
\hline South East & 0.79 & 0.54 & 0.81 & 0.54 & 0.94 & 0.54 & 0.97 & 0.54 \\
\hline South South & 0.79 & $0.36^{* * *}$ & 0.78 & $0.36^{* * *}$ & 0.77 & $0.37 * * *$ & 0.77 & $0.37 * * *$ \\
\hline South West & $0.53^{* *}$ & $0.25^{* * *}$ & $0.54 * *$ & $0.25^{* * *}$ & $0.50^{* * *}$ & $0.25^{* * *}$ & $0.51^{* * *}$ & $0.25^{* * *}$ \\
\hline $\mathbf{N}$ & 9,369 & 20,049 & 9,369 & 20,049 & 9,369 & 20,049 & 9,369 & 20,049 \\
\hline
\end{tabular}

1. $* * *: \mathrm{p}<.01 ; * *: \mathrm{p}<.05 ; *: \mathrm{p}<.10$ (borderline significance)

2. Year of child's birth is also included in the regression. 


\section{References}

ACAPS. (2017). Humanitarian Overview: An Analysis of Key Crises into 2018. Geneva.

ACLED. (n.d.). Retrieved November 12, 2017, from Armed Conflict Event and Location Data Project.

Akresh, R., Lucchetti, L., \& Thirumurthy, H. (2012). Wars and Child Health: Evidence from the Eritrean-Ethiopian Conflict. Journal of Development Economics, 99(2), 330-340.

Ascherio, A., Chase, R., Coté, T., Dehaes, G., et. al. (1992). Effect of the Gulf War on Infant and Child Mortality in Iraq. The New England Journal of Medicine, 327(13), 931-936.

Avogo, W. A., \& Agadjanian, V. (2010). Forced migration and child health and mortality in Angola. Social Science \& Medicine, 70(1), 53-60.

Blattman, C., \& Miguel, E. (2010). Civil War. Journal of Economic Literature, 48(1), 3-57.

Bustreo, F., Genovese, E., Omobono, E., Axelsson, H., \& Bannon, I. (2005). Improving Child Health in Post-Conflict Countries: Can the World Bank Contribute?

Cliff, J., \& Noormahomed, A. R. (1993). The Impact of War on Children's Health in Mozambique. Social Science \& Medicine, 36(7), pp. 843-848.

Coghlan, B., Brennan, R. J., Ngoy, P., Dofara, D., Otto, B., Clements, M., \& Stewart, T. (2006). Mortality in the Democratic Republic of Congo: a nationwide survey. The Lancet, 367(9504), 44-51.

Dabelen, A. L., \& Paul, S. (2014). Effect of Conflict on Dietary Diversity: Evidence from Côte d'Ivoire. World Development, 58, 143-158.

De Jong, J. T. (2010). A public health framework to translate risk factors related to political violence and war into multi-level preventive interventions. Social Science \& Medicine, 70(1), 71-79.

Delbiso, T. D., Rodriguez-Llanes, J. M., Donneau, A.-F., Speybroeck, N., \& Guha-Sapir, D. (2017). Drought, conflict and children's undernutrition in Ethiopia 2000-2013: a metaanalysis. Bulletin of the World Health Organization, 95(2), 94-102.

Demographic and Health Surveys. Retrieved November 16, 2017, from The DHS Program: https://dhsprogram.com.

DHS Program STATcompiler. Retrieved July 26 ${ }^{\text {th }}$, 2018, from The DHS Program: https://www.statcompiler.com/en/.

Devakumar, D., Birch, M., Osrin, D., Sondrop, E., \& Wells, J. C. (2014). The intergenerational effects of war on the health of children. BMC Medicine, 12(1), 57.

Guha-Sapir, D., Degomme, O., Teran, V., \& van Panhuis, W. G. (2005). Civil Conflicts in Four African Countries: A Five-Year Review of Trends in Nutrition and Mortality. Epidemiologic Reviews, 27(1), 67-77.

Idean Salehyan, Cullen S. Hendrix, Jesse Hamner, Christina Case, Christopher Linebarger, Emily Stull, and Jennifer Williams, "Social Conflict in Africa: A New Database," International Interactions 38, 4 (2012): 503-511.

International Food Policy Research Institute. (2015). Global Nutrition Report 2015: Actions and Accountability to Advance Nutrition and Sustainable Development. Washington, D.C.

Johnson, N.F., Gourley, S., Onnela, J-P., \& Reinert, G. (2008) Bias in epidemiological studies of conflict mortality. Journal of Peace Research, 45 (2), 653-663. 
Kruk, M. E., Freedman, L. P., Anglin, G. A., \& Waldman, R. J. (2010). Rebuilding health systems to improve health and promote state building in post-conflict countries: A theoretical framework and research agenda. Social Science \& Medicine, 70(1), 89-97.

Lindskog, E. E. (2016) The effect of war on infant mortality in the Democratic Republic of Congo. BMD Public Health.16, 1059.

Mashal, T., Takano, T., Nakamura, K., Kizuki, M., Hemat, S., Watanabe, M., \& Seino, K. (2008). Factors associated with the health and nutritional status of children under 5 years of age in Afghanistan: family behaviour related to women and past experience of warrelated hardships. BMC Public Health, 8(1), 301.

Maternal and Child Undernutrition Study Group. (2008). What works? Interventions for maternal and child undernutrition and survival. The Lancet, 371, 417-439.

Minoiu, C., \& Shemyakin, O. N. (2014). Armed conflict, household victimization, and child health in Côte d'Ivoire. Journal of Development Economics, 108, 237-255.

Nigeria Social Violence Project. (n.d.). Connect Africa. Retrieved November 16, 2017, from http://www.connectsaisafrica.org/research/african-studies-publications/socialviolence-nigeria/.

Pike, I. L., Straight, B., Oesterle, M., Hilton, C., \& Lanyasunya, A. (2010). Documenting the health consequences of endemic warfare in three pastoralist communities of northern Kenya: A conceptual framework. Social Science \& Medicine, 70(1), 45-52.

Project Ploughshares. Retrieved November 12, 2017, from Project Ploughshares: http://ploughshares.ca/pl armedconflict/nigeria-1990-first-combat-deaths.

Raleigh, C., Linke, A., Hegre, H., \& Karlsen, J. (2010). Introducing ACLED: An Armed Conflict Location and Event Dataset. Journal of Peace Research, 47(5), 651-660.

Safeguarding Health in Conflict Coalition. (2017). Impunity Must End: Attacks on Health in 23 Countries in Conflict in 2016.

Savitz, D. A., Thang, N. M., Swenson, I. E., \& Stone, E. M. (1993). Vietnamese Infant and Childhood Mortality in Relation to the Vietnam War. American Journal of Public Health, 83(8), 1134-1138.

Serdan, G.G. The Effects of the War in Iraq on Nutrition and Health: An Analysiis Using Anthropormophic Outcomes for Children. (2009) https://mpra.ub.unimuenchen.de/14056/1/Effects of the war in Iraq on Nutrition Revised Tables Fe b 2009.pdf

Skokić, F., Muratović, S., \& Radoja, G. (2006). Perinatal and Maternal Outcomes in Tuzla Canton during 1992-1995 War in Bosnia and Herzegovina. Croatian Medical Journal, 47(5), 714-21.

Spiegel, P. B., \& Salama, P. (2000). War and mortality in Kosovo, 1998-99: an epidemiological testimony. The Lancet, 355(9222), 2204-2209.

UNICEF. Retrieved December 2, 2017, from https://data.unicef.org/topic/childsurvival/neonatal-mortality.

Verwimp, P. (2012). Undernutrition, subsequent risk of mortality and civil war in Burundi. Economics and Human Biology, 10(3), 221-231.

World Health Organization. (2014). World Health Statistics, 2014. Geneva: WHO.

World Health Organization. (2015). Health in 2015 from MDGs to SDGs. Geneva, Switzerland: World Health Organization.

Young, H., Borrel, A., Holland, D., \& Salama, P. (2004). Public nutrition in complex emergencies. The Lancet, 364 (9448), 1899-909. 